\title{
Marriage, and Marital Problems and Solutions from the Perspective of Couples in Arranged Marriage
}

\author{
DOI: $10.26466 /$ opus. 898866
}

\author{
Zöhre Kaya* - Oya Onat Kocabıyık**-Seda Donat Bacığlu*** \\ *Assist. Prof. Dr., Van Yüzüncü Yıl University, Van/Turkey \\ E-Mail: zohrekaya@yyu.edu.tr \\ ORCID: 0000-0001-9211-3632 \\ ** Assoc. Prof. Dr., Tekirdağ Namık Kemal University, Tekirdağ/ Turkey \\ E-Mail: okocabiyik@nku.edu.tr \\ ORCID: 0000-0003-0449-2893 \\ *** Assist. Prof. Dr., Trakya University, Edirne/Turkey \\ E-Mail: sedadonatbacioglu@trakya.edu.tr \\ ORCID: 0000-0001-9901-0601
}

\begin{abstract}
The purpose of this study is to find out the opinions of couples in arranged marriage on marriage, problems encountered in marriage, and how to resolve problems and conflicts in marriage. In this study, the phenomenological approach - a qualitative research model - was adopted to define fully meanings attributed to the phenomenon of marriage by couples in arranged marriage. The study was conducted with a total of twelve participants, i.e. six couples in arranged marriage reached by six candidates that attended the family counseling certificate program delivered by a public-funded university in the Eastern Turkey in 2017-2018 academic year. The research data were records of interviews with couples analyzed through document analysis. Content analysis was conducted for descriptive analysis of the data. The results suggest that couples' evaluation of marriage fall under three major themes. Furthermore, sub-themes were identified under each theme. It was also found out that the participants' opinions varied by gender. Considering the medical, psychological and social effects of marriage, it is of particular importance to conduct multidimensional analyses of marriage for building a healthy society.
\end{abstract}

Key Words: Marriage, Arranged Marriage, Marriage Problems and Solutions, Gender. 


\section{Görücü Usulüyle Evlenen Çiftlere Göre Evlilik, Evlilikte Yaşanan Problemler ve Çözümü}

\section{Öz}

Bu çalışmanın amacl, görücü usulüyle evlenen çiftlerin evlilik, evlilikte yaşadıkları problemler ve bu problemlerin çözümüne yönelik düşüncelerinin belirlenmesidir. Araştırma, nitel araştırma modellerinden olgubilim desenine göre tasarlanmış olup bireylerin olguyla ilgili anlamların tam olarak tanımlamaya odaklanmaktadır. Araştırmanın çalışma grubunu, Türkiyénin doğusundaki bir devlet üniversitenin 2017-2018 Ĕ̆gitim-Öğretim yılı aile danışmanlığı sertifika programına devam eden altı farklı adayın ulaştığı görücü usulüyle evlenen altı farklı çift olmak üzere toplam oniki kişi oluşturmaktadır. Araştırmada, çalışma grubu ile yapılan görüşmelerden elde edilen belgelerin doküman incelemesi yapılmış ve veri kaynağı olarak kullanılmıştır. Elde edilen verilerin betimsel olarak çözümlenmesinde içerik analizi aşamaları takip edilmiştir. Araştırmadan elde edilen sonuçlar genel olarak değerlendirildiğinde, görücü usulüyle evlenen çiftlerin evliliklerini üç ana tema çerçevesinde değerlendirdikleri görülmektedir. Ayn zamanda bu ana temalar altında farklı temalarm olduğu ve cinsiyet değişkeni açısından farklılıklar gösterdiği tespit edilmiştir. Aile yapısının genel sağlık, psikolojik ve sosyal açıdan bireyler üzerindeki etkisi göz önüne alındığında, toplum sağllğ̆ açısından evlilik olgusunun çok boyutlu olarak incelenmesinin alanyazına önemli katkılar să̆layacağı öngörülmektedir.

Anahtar Kelimeler: Evlilik, Görücü Usulüyle Evlenme, Evlilik Problemleri ve Çözümü. 


\section{Introduction}

Constituting the foundation of the family and defined as a special and specific type of interpersonal relationship, marriage is an emotional, economic and social agreement concluded legally between two persons (Panganiban, 2007). It is a significant decision in adult life and the foundation stone of the family - the smallest unit of a society (Kublay and Oktan, 2015). According to Pamuk and Durmuş (2015), Individuals get married for numerous different reasons: to be happy, have children, establish an intimate relationship, satisfy sexual desires, and meet the expectations of the society. How people get married varies depending on cultural and economic conditions, settlement, relations of production, and traditions and customs in a society (Sezen, 2005). There is a wide spectrum of marriage types. While free-choice marriage becomes more widespread in cities with the effect of social and cultural transformations following industrialization and urbanization, there are different types of marriage in regions under greater influence of traditions (Sezen, 2005). One of these marriage types is arranged marriage associated particularly with traditional societies (Allendorf and Pandian, 2016; Baykara-Krumme, 2017; Hortaçsu, 1999; Pande, 2015). More common in the eastern societies than in the western part of the world (Mehndiratta, Paul, and Mehndiratta, 2007), arranged marriage is a type of marital union where the initial steps to choose a spouse are taken by parents or other family members. It is not enough that a young man likes and desires to marry a young woman; there is a need for family members' confirmation (Sezer, 2005). Arranged marriage was certainly more common in the past; however, studies have shown that it is still a common type of marriage in today's societies. For instance, a study conducted in India, where the rate of arranged marriage is the highest in the world, examined the trends in marriage choice between 1970 and 2000, and showed that arranged marriage is still common in the country although the rate of "love marriage" has increased especially in the northern part of India (Allendorf and Pandian, 2016). In Turkey, a meta-analysis covering the period between 2006 and 2016 demonstrated that $28.6 \%$ of couples had an arranged marriage while $71.4 \%$ chose their own spouse and got married after dating (Haylı, Durmuş, and $\mathrm{K}_{1}$, 2017). Altuntaş and Durmuş (2018) found out that 33.5\% of couples had an arranged marriage, and $24.5 \%$ chose a marriage partner through 
arrangement but got married after going on dates. The rate of arranged married was 28\% in Kublay and Oktan (2015), 43.1\% in Çimen (2007), and $36.2 \%$ in Çelik (2006). In a study conducted in Gaziantep, 50\% of marriages were arranged (Cingisiz and Murat, 2010). Type of marriage, as a cultural phenomenon, certainly affects marriage process, and was thus taken as the main variable in this study.

Previous research on marriage showed that there is no difference in marriage satisfaction and harmony between couples in arranged marriage and couples in free-choice one (Demiray, 2006; Kublay and Oktan, 2015). However, there are also studies suggesting that those in arranged marriage are not as satisfied with their marriage as couples in free-choice marriage (Çağ and Yıldırım, 2013; Çimen, 2007). The latter indicate that marriage satisfaction increases when individuals choose their own spouse and have the chance to get to know each other before marriage. In this respect, Özgüven (2000) drew attention to the importance of spending time before getting married, emphasizing that going on dates allows couples to get to know each other and hence to decide more easily. There is nevertheless research that points to the opposite, i.e. marriage satisfaction and quality is higher among couples in arranged marriage (Arif and Fatima, 2015; Demir and Durmuş, 2015; Yizengaw et al., 2014). Sinha and Ram's (2017) study on life satisfaction and subjective happiness of young women that chose a marriage partner through arrangement in India demonstrated that a large proportion of married young women are satisfied with general life conditions. Another study with 738 married men and 761 married women in Hong Kong (Shek, 1995) reported that the effect of marriage quality on individual welfare is greater in women than in men. Men generally reported greater marriage satisfaction than their spouses.

On the other hand, the conflict in the nature of human relationships is a variable that affects marital quality and marital satisfaction. Married couples may frequently experience conflict because of problems stemming from children, other family members and social circle. The Family Structure Research (2011) issued by the Directorate General for Family and Social Research identifies the problems between married couples. As the main sources of problems in marriage, men referred primarily to such issues as household responsibilities (33.4\%), child-related responsibilities $(29.1 \%)$, expenses $(56.9 \%)$, insufficiency of income $(25.2 \%)$, and insufficiency of 
shared time and activities (16.8\%). For women, the sources of marital problems were primarily household responsibilities $(37.2 \%)$, child-related responsibilities (32.5\%), expenses (29.3\%), insufficiency of income $(27.1 \%)$, insufficiency of shared time and activities (18\%), and husband's smoking habit (11.8\%) (Akça-Koca and Yüksel, 2017). Such marital problems generally derive from poor communication (Özgüven, 2000), high expectations and intolerance (Genç and Veli-Baki, 2017), and lack of conflict resolution skills (Ersanlı and Kalkan, 2008). Research suggests that harmony in marriage depends on how to deal with emerging conflicts rather than on lack of marital conflicts (Driver et al., 2003), and that the strategies used by couples in conflict resolution are of particular importance for a harmonious marriage (Soylu and Kağnıc1, 2015). Previous research further draws attention to the fact that conflicts due to lack of harmony are likely to arise if couples do not have positive communication and conflict resolution skills, and that lack of conflict resolution skills has negative effects on harmony in marriage (Ersanlı and Kalkan, 2008). Therefore, conflict resolution skills are important in marital relationships, just like in all interpersonal relationships.

It is known that arranged marriages are still the most common type of marriage today. According to a research carried out by the Ministry of Family on 12,208 households in 2006, 61 percent of marriages were arranged through arranged (ASPB, 2006). In the research conducted by the institution on 12,056 households after five years, the rate of arranged marriages was found to be 51 percent (ASPB, 2011). As can be seen, arranged marriage is still the most common form of marriage. In the literature there are several studies focusing on the comparison of types of marriage based on different variables; however, to our knowledge, there are no studies that focuses on opinions on marriage of couples in arranged marriage. Considering that the rate of arranged marriages, one of the types of marriage, is very high in the our country, collecting and analyzing data on the opinions of couples that wed through arrangement may provide practitioners with valuable information on problems and challenges specific to this type of marriage and help them develop more effective solutions to these problems. The data obtained about the marriage in this study are expected to play a guiding role in psychological support and counseling, and contribute significantly to preventive activities in family counseling. In the light of information presented above, the present study sets out to identify and define the view- 
points of couples in arranged marriage with regard to marriage in general, marital problems, and solutions of marital problems. The research questions were formulated as follows based on this general aim:

1. How do couples in arranged marriage define marriage?

2. What are the marital problems encountered by couples in arranged marriage?

3. How do couples in arranged marriage solve marital problems?

\section{Method}

Research Design: In this study, the phenomenological approach - a qualitative research model - was adopted to identify the viewpoints of couples in arranged marriage. The couples included in the study were contacted by the trainees that attended a family counseling certificate program. As phenomenology is an approach that aims to define how individuals make sense of a phenomenon, it examines individual experiences in detail from the firstperson perspective and collects data on participants' perception of a given phenomenon (Annells, 2006; Smith and Eatough, 2007).

Participants: The study was conducted with a total of twelve participants who volunteered to take part in the study - six couples in arranged marriage contacted by six trainees who attended the family counseling certificate program delivered by a public-funded university in the Eastern Turkey in 2017-2018 academic year.

Data Collection and Analysis: In this study, the trainees that attended the family counseling certificate program conducted interviews with couples in arranged marriage as a part of the program. The interview protocols used by the trainees were developed by the faculty members that led the family counseling certificate program delivered by a public university in the Eastern Turkey. For the purpose of this study, the trainees were asked to make interviews with couples using these protocols. Document analysis was conducted to examine the interview data. Document analysis, commonly used in qualitative research for the analysis of any recorded material, can be used for documents of all types including lesson plans, student assignments, 
tools and materials used in the class, and school and student records (Merriam, 2009).

Stages of content analysis were followed for descriptive analysis of interview data. The data were read meticulously by three researchers to ensure reliability. Meaningful units of analysis were determined for data coding. The researchers then developed themes from codes obtained in the preceding stage. Transferability can be ensured by describing themes in a detailed way. MAXQDA 12 software was used for data analysis and coding. Software use in data analysis allows building connections between themes owing to the retrieval function.

\section{Results}

Three themes were identified as a result of content analysis of data collected in this study: meaning of marriage, marital problems, and solution of marital problems. Table 1 presents the themes and codes obtained in the analysis.

The following sections of the study present findings related to each theme. Direct quotations from female and male participants were used to explain and describe the themes.

Meaning of Marriage: The primary purpose of the study was to identify how married couples make sense of marriage. The analysis of statements in interview forms provided the sub-themes of "trust and loyalty", "happiness and peace", "sharing", "respect", "social status" and "self-sacrifice" under the "meaning of marriage" category.

Referring to the place of "trust and loyalty", "Trust and loyalty are very important in marriage," said one of the male participants [ $3^{\text {rd }}$ couple-man; Position: 115-115], and "Trust and loyalty are at the very core of marriage," said a female participant [ $1^{\text {st }}$ couple-woman; Position: 109-109]. With regard to "happiness and peace", "Marriage is peace, happiness," said a man [ $1^{\text {st }}$ coupleman; Position: 105-105], while a woman defined marriage as "a happy and peaceful nest in which there are children" [2 ${ }^{\text {nd }}$ couple-woman; Position: 112-112]. "Sharing" was defined by a male participant as "doing everything together, taking on everything together" [ $5^{\text {th }}$ couple-man; Position: 14-14], by a female participant as "sharing life" [1 $1^{\text {st }}$ couple-woman; Position: 11-11]. One of the male participants stated that "respect is very important" [2 2 nd couple-man; Posi- 
tion: 12-12], and one of the female participants stressed that marriage is "showing respect" [2 $2^{\text {nd }}$ couple-woman; Position: 110-110]. Finally, the concepts of "social status" and "self-sacrifice" were emphasized by only male participants. While one of them defined marriage literally as "gaining a place in social status [a means for raising social status]" [ $6^{\text {th }}$ couple-man; Position: 14$14]$, another one referred to it as "self-sacrificing" [ $5^{\text {th }}$ couple-man; Position: 113-113].

Table1. Opinions of couples in arranged marriage on meaning of marriage, marital problems, and solution of marital problems

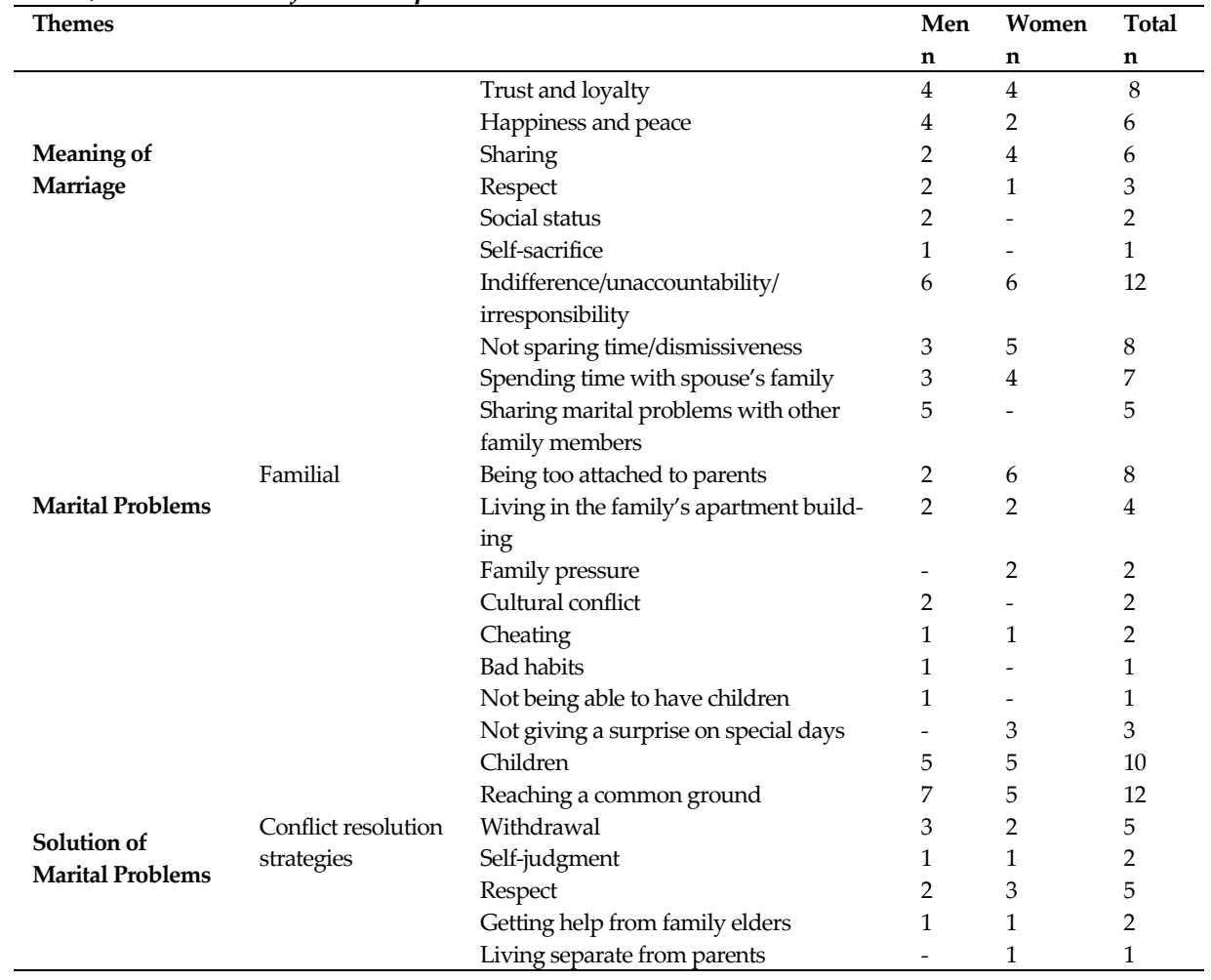

Marital Problems: The second purpose of the study was to identify the problems encountered by couples in arranged marriage. The analysis of statements in interview forms provided, under the theme of "marital problems", the sub-themes of "being indifferent/unaccountable/irresponsible", "not sparing time/being dismissive", "spending time with spouse's family", "sharing 
marital problems with other family members", "being too attached to parents", "living in the family's apartment building", "family pressure", "cultural conflict", "cheating on the spouse", "bad habits", "not being able to have children", and "not giving a surprise on special days".

With regard to "indifference/unaccountability/irresponsibility", "She doesn't fulfill some of her responsibilities completely. For example, it is very difficult for her to start doing something," said a man [3 $3^{\text {rd }}$ couple-man; Position: 69-69], and "He doesn't make repairs at home. He is so indifferent. I would love to change his attitude about this," said a woman [5 $5^{\text {th }}$ couple-woman; Position: 30-30]. "Not sparing time/being dismissive" was another problem in marriage. "We have problems because I don't spend enough time with kids," one of the male participants noted. "He is on the internet until midnight. He doesn't spare time for $m e, "$ said a female participant $\left[4^{\text {th }}\right.$ couple-woman; Position: 66-66].

Married couples also referred to problems arising from families, one of which was related with "spending time with spouse's family". "My family lives out of town. When they come to the town, they stay at our place, and my wife is not happy with this," said a male participant [3 $3^{\text {rd }}$ couple-man; Position: 6363]. "The problem did not have to do with my marriage. But we had to live at my inlaw's place, and I had problems with mother-in-law. I didn't want to stay there," said a female participant about spending time with spouse's family [ $5^{\text {th }}$ couple-woman; Position: 91-91]. "Sharing marital problems with other family members" was a familial problem which was mentioned only by men. "My wife shares our problems with her mother rather than try to solve them with me," said a man [1 ${ }^{\text {st }}$ couple-man; Position: 15-15]. Another problem was "being too attached to parents". "The problem is that I support my parents, not my wife, when we are faced with problems due to common life," reported a man [2 $2^{\text {nd }}$ couple-man; Position: 86-86]. Similarly, "I blame my husband because he always supports his family when we have a conflict [because of the family]," said one of the female participants [ $2^{\text {nd }}$ couple-woman; Position: 55-55]. Another familyrelated problem was "living in family's apartment building". "We live in the family apartment but no respect is shown to decisions we need to make jointly. And this still goes on," said a male participant [2 ${ }^{\text {nd }}$ couple-man; Position: 18-18]. "We live in the family apartment, but other family members do not respect rules of common life in the building. My husband and I have to take the entire burden on ourselves," said a woman [2 ${ }^{\text {nd }}$ couple-woman; Position: 13-13]. "Family pressure" was a problem mentioned only by women. According to a woman 
among participants, "The greatest problem is family pressure, pressure by fatherin-law and mother-in-law, but my husband is always kind to me." [4 $4^{\text {th }}$ couplewoman; Position: 16-16]

Another problem uttered only by men was "cultural conflict". The participant who referred to this problem said the following [2 ${ }^{\text {nd }}$ couple-man; Position: 16-16]: "We have a cultural conflict because we are from two different towns. We have problems because of this especially when we need to make common decisions about the family." "Cheating" was another marital problem mentioned by couples in arranged marriage. Specific comments included the following: "I had a girlfriend 13 years ago," said a man [4 $4^{\text {th }}$ couple-man; Position: 44-44]. "During our marriage, in two different periods of time, my husband used to change his clothes twice a day. I was aware he was in love with someone else. However, he could never make me talk about this issue. To apologize, he took me to Istanbul for IVF treatment," a female participant explained [4 $4^{\text {th }}$ couplewoman; Position: 44-44]. "Bad habits" was mentioned as a problem only by men: "I used to gamble, I hadn't been able to bring home food. There had been a period in my life in which I beat my wife and took her earrings by force [to sell them], I borrowed from our neighbors. I then came to senses. I quitted gambling and smoking." [ $4^{\text {th }}$ couple-man; Position: 16-16]. Another problem indicated only by men was "not being able to have a baby". "We cannot have a baby. Because of this, I avoid seeing couples at our age. Those couples' interest in their kids is like showing off. My wife and I then have problems at home. That is why I generally prefer hanging out with elder people," he said [4 $4^{\text {th }}$ couple-man; Position: 18-18]. "Not giving a surprise on special days" was a problem mentioned only by women. A specific comment was as follows: "I feel upset deep down because he doesn't take care of me and doesn't buy me flowers on special days. One day I bought myself flowers. My husband asked me why I bought those flowers. 'I try to make myself happy because you don't do it on special days,' I told him." [2 $2^{\text {nd }}$ couple-woman; Position: 66-66].

Solution of Marital Problems: The third purpose of the study was to find out how couples solve marital problems. The analysis of interview forms provided, under the theme of "solution of marital problems", the subthemes of "children", "reaching a common ground", "withdrawing", "selfjudgment", "respect", "getting help from family members", and "living apart". 
The couples referred to the importance of having "children" as a solution for marital problems: "Kids are important. I would stay together for them," said a male participant [ $5^{\text {th }}$ couple-man; Position: 40-40], and "Yes, the child is also important. We have a child, so we can't do anything that impairs his development," said a female participant [1 ${ }^{\text {st }}$ couple-woman; Position: 37-37].

"Reaching a common ground" was another problem-solving strategy mentioned by the couples. A male participant said the following about this: "We solve our problems talking to each other. There is no need to consult others. We solve them together." [1 $1^{\text {st }}$ couple-man; Position: 17-17]. Similarly, a woman referred to the importance of "mutual support, not solving problems unilaterally" [6 $6^{\text {th }}$ couple-woman; Position: 20-20]. Another strategy was "withdrawal" in the sense that the couples do not take action and remains silent about problems they experience. "I would withdraw to save my marriage," said a man [2 $2^{\text {nd }}$ couple-man; Position: 27-27], and parallelly "I would shut myself home [I would withdraw from social life]. I would try not to make known what is going on," said a woman [ $4^{\text {th }}$ couple-woman; Position: 92-92]. The couples further mentioned "self-judgment" as a strategy for fixing marriage. "I judge myself. I remain silent if I have made a mistake. If I know I am wrong, I try to make up for it," said a man [4 $4^{\text {th }}$ couple-man; Position: 58-58]. "If our marriage was under threat because of me, I would try to fix my mistakes. But if there is a mistake on my husband's part, I would expect him only to try," said a female participant [2 ${ }^{\text {nd }}$ couple-woman; Position: 24-24]. Another strategy mentioned by the couples was showing "respect". "I expect everyone, including my spouse, to be wise and respectful," said a man [2 $2^{\text {nd }}$ couple-man; Position: 20-20]. A female participant stated that she would expect her husband "to show respect and to understand" her [1 ${ }^{\text {st }}$ couple-woman; Position: 17-17].

The couples also referred to the place of "getting help from family members", especially elder members. A male participant mentioned that he would "get help from family elders" to solve marital problems [ $6^{\text {th }}$ couple-man; Position: 27-27], and a female participant said that she would "consult to family elders, to elder sister and brother" [6 ${ }^{\text {th }}$ couple-woman; Position: 27-27].

Only women referred to the importance of "staying separate from parents" as a solution for marital problems. "We have to live separate from our family elders to solve problems in our marriage, in other words everyone needs to live in their own place," she said [2 ${ }^{\text {nd }}$ couple-woman; Position: 17-17]. 


\section{Discussion, Conclusions and Recommendations}

This study examined the perceptions and opinions of couples in arranged marriage with regard to marriage in general, problems in marriage, and solution of marital problems. The findings of the first question of the research regarding how married couples define "marriage" are as follows: Firstly, the couples emphasized the importance of trust and loyalty when defining marriage. This result confirms Pamuk and Durmuş (2015), who found that trust is a significant factor that is instrumental in marriage harmony and satisfaction, and that marital relationships in which spouse support and mutual trust are lacking and spouses experience interpersonal cognitive distortion cause marriage burnout. Another research showed that, in arranged marriages, the rate of insecure attachment between spouses is higher, and that couples in arranged marriage have lower levels of emotional relationship and experience problems more frequently (Hortaçsu, 1999). Associating this finding with the results of our study, we can conclude that couples emphasize the importance of trust in marital relationship as they tend to link trust with attachment and emotional relationship and consider it indispensable for an ideal marriage. Another conclusion regarding the definition of marriage is that both women and men in arranged marriage also referred to the significance of happiness and peace in marriage, sharing in marriage and respect. This concurs well with previous studies (Pamuk and Durmuş, 2015; Demir and Durmuş, 2015; Yizengaw, et.al, 2014). Especially, in Demir and Durmuş (2105) research with married individuals for many years, it was reported that the secret of couples is to build a happy home and share life. And also, the couples reported that they also solved the problems in their marriage peacefully. Kublay and Oktan (2017) found that subjective happiness is a significant and important predictor of harmony in marriage, in Russell-Chapin, Chapin, and Sattler (2001) research indicated that couples' together time, shared interests and activities, and shared decision making are factors that nurture the marital relationship, reduce conflicts, and increase marriage satisfaction. According to Çağ and Yıldırım (2013), in successful marriages, couples generally have physical, social and emotional affection and feel that they are loved, valued and respected by the spouse. In general, research findings show that couples attribute positive meanings to the "marriage" phenomenon. Consistent with our finding, other 
studies focus on factors such as commitment, trust, diligence, patience, respect, self-sacrifice and responsibility for a long-haul marriage relationship (Canel, 2012). In the present study, only men referred to social status and self-sacrifice in their definition of marriage. Previously, Kephart (1966) reported that people tend to get married to build social status (qtd. in Demir and Durmuş, 2015). Özgüven (2001) also reported that raising social status is one of the main functions of family. As an arranged marriage typically builds upon men's choice in our culture, the female participants of this study had not had the chance to choose their spouse. That is probably why they did not make any reference to social status considering that they did not have control over the social status of their spouse. Furthermore, women probably did not mention self-sacrifice as they have already internalized this trait due to gender roles culturally and socially attributed to women.

The second question of the study was about what the marital problems couples encounter in an arranged marriage. The findings indicate that indifferent, unaccountable and irresponsible attitudes of spouses are defined as a problem by both women and men. Previous studies also showed that taking responsibility, promoting openness in communication, and positive personality traits such as empathy have a significant effect on marriage satisfaction (Soylu and Kağnıc1, 2015; Tutarel-Kışlak and Çabukça, 2002). Also, sharing household responsibilities and plays a considerable role in marital relationships and perceived level of spouse support increases together with increased sharing of household chores (Çă̆ and Yıldırım, 2013). Altuntaş and Durmuş (2018) found a significant relationship between sharing household chores and problem solving in marriage, and reported that spouses that share household chores have higher marital problem-solving scores than couples that sometimes or never share household chores. They also found that the variables of perceived spouse support and sharing household responsibilities together explain 51\% of problem solving in marriage. Spouse support is the most significant predictor, explaining $48 \%$ of problem solving. Contrary to these findings, Çăg and Yıldırım (2013) reported that sharing household responsibilities is not a significant predictor of marriage satisfaction. In the present study, both female and male participants also referred to not sparing time and being dismissive as major marital problems. While Demir and Durmuş (2015) noted that dismissiveness is the least indicated marital problem, Canel (2012) emphasized that sparing time for each other 
in marriage leads to a decrease in marital conflicts and an increase in trust and intimacy between couples, and hence contributes substantially to the increase of marriage satisfaction. It was also reported that individuals with greater marital satisfaction are happier, and have better mental health and a healthier marriage. Some other marital problems mentioned by couples in arranged marriage were related with families. Both women and men referred to problems such as spending time with spouse's family, being too attached to parents, and living in the family's apartment building. Our findings bear a close resemblance to Canel (2012), who reported family-related problems such as spending too much time with spouse's family, being too attached to parents, lack of autonomy from parents, and being financially dependent on parents. With regard to familial problems, some male participants added that wives tend to share marital problems with other family members whereas some female participants referred to family pressure. Parents and other family members may be a source of support, but also a source of stress (Canel, 2012). Women feel family pressure because, in some cases, couples have to live with parents as a result of continuing traditional family norms. Therefore, family-related problems may be linked to cultural and traditional family structure and to forms of relationship in such families. In this study, men also underlined cultural conflict as a reason for marriage problems. Meanings people attribute to events, persons, relationships, words and behaviors are shaped by dynamics of the culture in which they live (Cüceloğlu, 2017). As a multicultural society, Turkey presents a wide spectrum of customs, beliefs, conventions and traditions. Differences in food, clothing, social life norms, sharing household chores, feast and special day customs, socioeconomic situation of families and habits are all likely to cause cultural conflicts between couples.

Both men and women referred to cheating as another marital problem. Cheating is not only a source of problems in marriage but also one of the main factors that lead to termination of a marriage. From the perspective of gender, Hansen (1985) stated that traditional gender roles cause dependency and feeling of inadequacy in women, which makes extramarital affairs terrifying for women. Men are inclined to cheat on their spouses more frequently than women since there is no such pressure for them. For Shackelford (2001), the spouse's fidelity is the strongest predictor of a man's level of self-esteem, signaling that men on which their wife cheated have low self- 
esteem. The present study further revealed that married couples experience problems due to bad habits of a spouse. This problem was mentioned only by men. A marriage is affected negatively when either of the spouses has a bad habit. In Canel's (2012) study, the sources of problems in marriage are bad habits such as alcohol and drug use and gambling, lack of respect between spouses, and spouses' irresponsibility with regard to marital roles. Another problem mentioned only by men is not having a child. Consistent with this finding, Canel (2012) reported that private issues such as not having children or disagreement on the number of children, cheating and jealousy are among problems experienced in marriage. Finally, women referred to not giving a surprise on special days as a marriage problem. Giving a surprise may be connected with romance but also with family customs. In a traditional family structure, men are generally not expected to give a surprise. However, the research results suggest that women still expect surprises from spouses. This is an indicator of the fact that they give importance to emotional processes.

The final question of the study was how couples in arranged marriage solve marriage problems. Having children was mentioned by both men and women as an essential factor for continuing their marriage despite problems. In other words, couples tend to put up with marriage for the sake of the children. Wallerstein (1992) reported that unhappy couples indicate children as a reason to stay married. On the other hand, in the present study, the male participants indicated that not having children is a marital problem. In fact, one of the couple's greatest wishes in their new life is to have a child. However, it is possible to say that having children in marriage is not only a source of great happiness and satisfaction, but also a source of great trouble. Having kids has both positive and negative effects on marriage - both complementing the family and presenting several difficulties on the other hand (Altuntaş and Durmuş, 2018). From a positive aspect, children are reported to be a fruit of couples' love and affection for each other and to have positive effects on the marital relationship. From a negative aspect, children are reported to be a source of problem in marriage and to cause disharmony by hampering a close relationship between couples (Belsky, 1990). Hicks and Platt (1970) noted that having children is a factor that has such effects on marriage as poor communication, financial difficulties and problems in sharing household chores, and also affects marriage 
satisfaction. In the present study, children are seen as a significant factor in problem solving on the one hand, and not having children is seen as a source of problem on the other hand. This is mainly because, in the eastern societies with traditional families, children are perceived as a considerable source of power. Another finding from the study is that both men and women stated that "reaching common ground" - that is, acting together and promoting mutual communication to find a solution - is an important way of solving problems in marriage. Harmony is an important factor for a positive and effective marriage experience as it affects physiological and mental health of all family members (Ersanlı and Kalkan, 2008). Couples that try to find a common ground for issues related with marriage and family and that solve problems together are often considered to be in a harmonious marital relationship (Erbek et al., 2005). Building on common ground in problem solving, democratization of family relationships and determination to solve marital problems are factors signaling that social support mechanisms between couples are functioning in a marriage (Papp, Kouros, and Cummings, 2010; Tallman and Hsiao, 2004). Scanzoni (1995) noted that problem-solving skills are instrumental in promoting shared decision-making in couples and hence improve their communication skills, and by doing so, encourage them to be mutually more thoughtful and helpful. On the other hand, in this study, both female and male participants stated that they used withdrawal and self-judgment strategies to admit and compensate for their mistakes. In addition, both men and women highlighted the importance of mutual respect in solving problems. Canel (2012) reported that marital conflicts usually result in obedience, renunciation, withdrawal, and reconciliation, but this situation basically does not solve the problem. In the literature, consistent with the findings of this study, data are presented that couples establish and maintain a healthier marital relationship when they are loyal to each other, show mutual respect and love, can resolve conflicts, and communicate effectively (Altuntaş and Durmuş, 2018; Demir and Durmuş, 2015).The last problem-solving method mentioned by men and women was getting help from family members especially elders. Canel (2012) also emphasized that couple' parents and other family members may be sources of support in marriage. Interference with parents, couples' relationships or lives has positive and negative consequences. From time to time, these interventions contribute to transferring experiences to new couples, providing financial support, and 
overcoming marital problems, while some interventions - even if well intentioned - can lead to serious marital problems and family discussions (K1zmaz and Altuğ, 2019).In the study, some female participants also focused on the nuclear family and living separate from in-laws as a solution of marital problems. L'abate (1994) mentioned that women are often affected by problems related to the spouse's family and that problem between the daughterin-law and the mother-in-law generally lead to conflict. In the present study as well, women consider that living with parents is a problem, and hence, the solution of this problem would be living apart from parents.

In sum, the results of this study indicate that meaning attributed to marriage, marriage problems and solutions of marriage problems play a significant role in marital relationships. However, the results reported herein are restricted with data collected from a small group of participants. Individuals must be provided with premarital and marital counseling services in consideration of conclusions and recommendations of scientific research on marriage. Premarital counseling services need to include psychoeducation programs such as coping with stress, conflict resolution, organizing social relationships, problem solving, anger management and communication skills. Furthermore, wide-reaching marital/family counseling services are likely to help family members build more effective relationships and thus contribute to promoting mental health in the society. Suggestions for delivering marriage and family counseling services are as follows:

Psychoeducation programs, including sexual education, can be organized in secondary and higher education institutions to prepare young people for marriage and family life.

Municipalities can provide pre-marital counseling to couples who apply for marriage.

In mosques, coffee houses, workplaces, men can be informed about issues such as how to communicate with their spouses, the importance of healthy family relationships and spousal support.

Family-related institutions and departments can carry out family counseling services in public trainings and women and community centers, family practice and / or home visits. 


\section{References}

Akça-Koca, D. and Yüksel, M. Y. (2017). Bir Aile Eğitim Programının evli annelerin evlilik doyumu, evlilikte sorun çözme becerisi ve psikolojik iyi oluşuna etkisi. International Journal of Field Education, 3(1), 1-19.

Allendorf, K. and Pandian, R.K. (2016).The decline of arranged marriage? Marital change and continuity in India. Population and Development Review, 42(3), 435-464.https://doi.org/10.1111/j.1728-4457.2016.00149.x.

Altuntaş, S. and Durmuş, E. (2018).Evlilikte problem çözmeyi yordayan değişkenlerin incelenmesi. Pamukkale Üniversitesi Sosyal Bilimler Enstitüsü Dergisi, 30, 321-331.https://doi.org/10.16953/deusosbil.528570.

Annells, M. (2006). Triangulation of qualitative approaches: Hermeneutical phenomenology and grounded theory. Journal of Advanced Nursing, 56(1), 55-61.https://doi.org/10.1111/j.1365-2648.2006.03979.x.

Arif, N. and Fatima, I. (2015).Marital Satisfaction in different types of Marriage.Pakistan Journal of Social and Clinical Psychology, 13(1), 36-40.

Baykara-Krumme, H. (2017). Impacts of migration on marriage arrangement: A comparison of Turkish families in Turkey and Western Europe. Journal of Family Issues, 38(15), 21502177.https://doi.org/10.1177/0192513x15594205.

Belsky, J. (1990). The effects of children on marriage.The psychology of marriages conceptual, emprical and applied contributions (Ed: Fincham, D. F.; Bradbury, T.M.). New York: Guilford Press.

Cingisiz, N. and Murat, M. (2010). Investigation the levels of emotional intelligence of the couples making decision for marriage. Gaziantep University Journal of Social Sciences, 9(1), 99-114.

Cüceloğlu, D. (2017). Evlenmeden önce. 1. Basım. İstanbul: Remzi Kitabevi.

Çağ,P. and Yıldırım, İ. (2013). Evlilik doyumunu yordayan ilişkisel ve kişisel değişkenle.Türk Psikolojik Danışma ve Rehberlik Dergisi, 4(39), 13-23.

Canel, A. N. (2012). Aile eğitim programı: Evlilik ve aile hayatı. Ankara: Aile ve Sosyal Politikalar Bakanlığ Yayınları.

Chang, C.Y. and Myers, J. E. (1997). Understanding and counseling Korean Americans: Implications for training. Counselor Education and Supervision, 37, 35-49.https://doi.org/10.1002/j.1556-6978.1997.tb00529.x.

Çimen, Ş. E. (2007). Görü̈ü usulü ve anlaşarak evlenen bireylerin çeşitli sosyal psikolojik faktörler yönünden karşlaştırılması. (Yayınlanmamış Yüksek Lisans Tezi). Ankara Üniversitesi, Sosyal Bilimler Enstitüsü, Ankara. 
Demir, Y. and Durmuş, E. (2015). Uzun evlilikler: Bir yastıkta kırk yıl. Journal of International Social Research, 8(36).

Demiray, Ö. (2006). Evlilikte uyumun demografik özelliklere gore incelenmesi.(Yayımlanmamış Yüksek Lisans Tezi). Dicle Üniversitesi, Sosyal Bilimler Enstitüsü, Diyarbakır.

Driver, J., Tabares, A., Shapiro, A., Nahm, E. Y., and Gottman, J. M. (2003). Normal family processes: Growing diversity and complexity. F. Walsh (Ed), Interactional patterns in marital success or failure: Gottman Laboratory studies (p.493-513). New York: Guilford.

Erbek, E., Beştepe, E., Akar, H., Eradamlar, N., and Alpkan, R. L. (2005).Evlilik uyumu.Düşünen Adam, 18(1), 39-47.

Ersanl, K. and Kalkan, M. (2008). Evlilik ilişkilerini geliştirme (Kuram ve Uygulama). Ankara: Nobel Yayın Dağııım.

Genç, Y. and Veli-Baki, S. (2017). Eşler Arası Çatışmaya Neden Olan Faktörler. Electronic Turkish Studies, 12(21), 299-314. https://doi.org/10.7827/turkishstudies.12098.

Hansen, G. L. (1985). Perceived threats and marital jealousy.Social Psychology Quartery, 48, 262-268.https://doi.org/10.2307/3033686.

Hayll, R. G., Durmuş, E. and Kış, A. (2017). Evlilik doyumunun evlenme biçimi açısından incelenmesi: Bir meta-analiz çalışması. Electronic Turkish Studies, 12(28), 429-444.

Hicks, M.W. and Platt, M. (1970). Marital happiness and stability: A review of the research in the sixties. Journal of Marriage and The Family, 32, 553574.https://doi.org/10.2307/350251.

Horçatsu, N. (1999). İnsan ilişkileri.Birinci Baskı. Ankara: İmge Yayınları.

Kephart, W. M. (1966). The family, society and individual. Bostan: Houghton Mifflin Company.

Kızmaz, Z. and Altuğ, S. (2019). Aile Sorunlarının Ortaya Çıkmasında Ebeveyn Müdahalelerinin Etkisi. BEÜ SBE Dergisi., 8(2), 538-557

Kublay, D. and Oktan, V. (2015). Evlilik uyumu: Değer tercihleri ve öznel mutluluk açısından incelenmesi. Türk Psikolojik Danışma ve Rehberlik Dergisi, 5(44), 25-35.https://doi.org/10.29250/sead.787675.

L'Abate, L. (1994). Why evaluate families. A psychological approach: Family evulation. London:Sage Publications.

Mehndiratta, M.M., Paul, B., and Mehndiratta, P. (2007). Arranged marriage, consanguinity and epilepsy. Neurology Asia, 12(1), 15-17. 
Merriam, S. B. (2009). Qualitative research: A guide to design and implementation: Revised and expanded from qualitative research and case study applications in education. San Franscisco: Jossey-Bass.

Özgüven, İ. E. (2000).Evlilik ve aile terapisi.Ankara: PDREM Yayınları.

Özgüven, İ.E. (2001). Ailede iletişim ve yaşam. Ankara: PDREM Yayınları.

Pamuk, M. and Durmuş, E. (2015). Investigation of burnout in marriage.Journal of Human Sciences, 12(1), 162-177.

Panganiban, A. V. (2007). The rings of a happy marriage. Philippine Daily Inquirer, A13.

Papp, L. M., Kouros, C. D. and Cummings, E. M. (2010). Emotions in marital conflict interactions: Empathic accuracy, assumed similarity, and the moderating context of depressive symptoms. Journal of Social and Personal Relationships, 27(3), 367387.https://doi.org/10.1177/0265407509348810.

Pande, R. (2015). I arranged my own marriage': Arranged marriages and postcolonial feminism. Gender, Place and Culture, 22(2), 172187.https://doi.org/10.1080/0966369x.2013.855630.

Russell-Chapin, L. A., Chapin, T. J., and Sattler, L. G. (2001). The relationship of conflict resolution styles and certain marital satisfaction factors to marital distress. The Family Journal, 9(3), 259-264. https://doi.org/10.1177/1066480701093004.

Sezen, L. (2005). Türkiye'de evlenme biçimleri. A.Ü. Türkiyat Araştırmaları Enstitüsü Dergisi, 27, 185-195. https://doi.org/10.14222/turkiyat674.

Scanzoni, J. (1995). Contemporary families and elationships: Reinventing responsibility. New York, NY: McGraw-Hill.

Shek, D.T.L. (1995). Gender differences in marital quality and well-being in Chinese married adults Sex Roles,32, 699-715. https://doi.org/10.1007/bf01560185.

Shackelford, T.K. (2001). Self-esteem in marriage. Personality and Individual Differences, 30, 371-390. https://doi.org/10.1016/s0191-8869(00)00023-4.

Smith, J. A. and Eatough, V. (2007). Analysing qualitative data in psychology.(Ed. Lyons, E., andCoyle, A). London: Sage Publications.

Soylu, Y. and Kağnıcı, Y.D. (2015).Evlilik uyumunun empatik eğilim, iletişim ve çatışma çözme stillerine gore yordanması.Türk Psikolojik Danışma ve Rehberlik Dergisi, 5(43), 44-54. 
Tallman, I. and Hsiao, Y. L. (2004). Resources, cooperation, and problem solving in early marriage. Social Psychology Quarterly, 67(2), 172-188. https://doi.org/10.1177/019027250406700204.

Tutarel-Kışlak, Ş. and Çabukça F. (2002). Empati ve demografik değişkenlerin evlilik uyumu ile ilişkisi. Aile ve Toplum Dergisi, 25, 35-42. https://doi.org/10.1501/sbeder 0000000044.

Türkiye İstatistik Kurumu (TÜİK). (2018). Evlenme ve boşanma istatistikleri.Erişim adres: http://www.tuik.gov.tr/PreHaberBultenleri.do?id=27593.

Wallerstein, J. S. (1992). Children after divorce. Marriage and Family. Guilford, CT: Dushkin.

Yizengaw, S. S.,Kibret, B. T., Gebersuli, A.G., and Sewasew, D. T. (2014). Marital adjustment among early, age-appropriate arranged and love-matched marriage, Motta, North West Ethiopia. Innovare Journal of Social Sciences, 2(4), 65-73.

\section{Citation Information}

Kaya, Z., Onat Kocabıyık, O., and Donat Bacıŏlu, S. (2021). Marriage, and marital problems and solutions from the perspective of couples in arranged marriage. OPUS-International Journal of Society Studies, 18(42), 5187-5207.DOI:10.26466//opus.898866. 